\title{
Perception of Tourist towards the Potential Development of Tumpa Mountain Area as Integrated Ecotourism, Manado, North Sulawesi Province
}

\author{
Benny Irwan Towoliu*, Mita Erdiaty Takaendengan \\ Department of Tourism, State Polytechnic of Manado, Indonesia
}

\begin{abstract}
Tumpa is the name of mountain located at the northern part of the Manado City region which bordering The National Park of Bunaken. As a mountainous region with a height of $\pm 623 \mathrm{~m}$ (asl), it occupies a strategic position. In addition to being adjacent to the park, it is also part of uplands owned by the city of Manado. It serves as buffer zone (green belt) of water, horticultural and agricultural areas with mangrove coastal areas. Master Plan of Tourism Development Region in Manado City used as part of ecotourism products from mountain and forest, but so far there has been no in-depth study to assess the holistic perception of tourist in the development potency of the region as an integrated tourism in Tumpa Mountain area. This study was purposed to determine the tourist perception toward the potential development as integrated ecotourism. This research involved a qualitative research approach, described by using figures on the percentage. Fieldwork was used as a questionnaire survey. The analysis measurement using Likert Scale, scoring and analysis combined with the analysis of the interest rate (level of importance). This study result shows that the average respondent answered good with the score range between 3.5 until 4.2. It means the respondents have argued that every indicator; natural, social-cultural and infrastructure that exists in the region Tumpa Mount area is still in good condition. In the level of interest the respondents answered between 3.6 until 4.6 with category important. This means respondents expect that good environmental circumstances will be always maintained and linked with the development of tourist attraction which is very suitable to be developed as ecotourism. In conclusion, the indicators are considered good and important to be developed as an integrated ecotourism area.
\end{abstract}

Keywords: Ecotourism, Integrated, Perception, Tourist, Tumpa Mount.

\section{INTRODUCTION}

Ecotourism is a form of alternative tourism replacing mass tourism types that are considered to over exploit the natural environment and social culture. Ecotourism is currently developed by many countries around the world. In addition, eco-tourism is considered as a form of tourism that does not damage the ecological environment and social culture, and nature to conserve a life that degraded or threatened with extinction.

Ecotourism, in contrast to nature, requires additional requirements for nature conservation. Thus ecotourism is natural tourism with mild impact that caused to require maintenance of species and their habitats directly with its role in the preservation and or indirectly by giving a viewpoint to the local community. It was aimed to the local community to be able to put a value, and protect the nature and lives as a source of income.

Besides that, ecotourism also increase the awareness of visitor to conserve the natural

\footnotetext{
* Correspondence address:

Benny Irwan Towoliu

Email : benny.tourism@gmail.com

Address : Campus of Polytechnic. JL. Politeknik Ds Buha Manado PO BOX 1256
}

environment [1]. The International Ecotourism Society [2] defines ecotourism as responsible for travelling to nature areas that conserve the environment and improves the well-being of local people. It is also defined as traveling in charge with the conservation of the environment and the welfare of the host community.

The viewpoint on ecotourism is not just limited on visiting the nature but also responsible for the sustainability of the region [3-9]. Damanik and Weber [10] states that ecotourism perspective consists of three parts: 1. Ecotourism as a product; 2. Ecotourism as market, ecotourism development support local businesses that provide benefits to the local community [11]; and 3. Ecotourism acts as development approach. Furthermore Damanik and Weber [10] describe that as a product; ecotourism is all the attractions based on natural resources. Ecotourism market is a journey that is directed at environmental conservation efforts as well as the approach to development, ecotourism is a method of resource utilization and management of eco-friendly tourism.

Manado is the capital of North Sulawesi province and part of the Republic of Indonesia. In 2010, Manado has set the vision of region as a Model of Ecotourism City. But the emphasis is on 
marine ecotourism as the main base; Bunaken National Park as a tourist icon. The strategic position of Manado is located on the bay facing the Pacific Ocean. However, the existence of Manado cannot be separated from the mainland element of mountains and hills that form the topography of the city which is also located between the hills. Tourism development focus has been in the maritime sector, caused the land (terrestrial) sector does not get a priority to be developed. It can be seen from the profile tourists visiting North Sulawesi which almost 95\% [12] aimed to Bunaken National Park. This trend is also seen in the flow of tourists who visit in Manado every year, the highest in May to October [13], then decreased from November to April. The flow of tourists is mainly influenced by weather conditions in the sea of Manado and surrounding areas. Travelers had only intended to go to Bunaken Marine Park and there are no other alternative tourist sites that can be visited. Due to the uneven deployment, it motivates the government of Manado to create a plan development of mainland area.

Manado City Government in 2012 has planned to encourage the development of tourism sector by relying on mainland natural planned areas surrounding mountains in the city of Manado. The Master Plan of Regional Tourism Development (RIPPDA) of Mount Tumpa is prioritized as an area of ecotourism product development on mountains and forests. This location is actually a water buffer zone in Manado City and surrounding areas. This location is the highest plateau in the city of Manado and the surrounding lowland which serves as plantation areas and the community agriculture, due to its adequate soil fertility. Soil fertility levels of 432.24 ha is relatively fertile and the rest ( $251 \mathrm{ha}$ ) was moderate, with a depth of up to $50 \mathrm{~cm}$ soil solum. Solum depth level is very useful for the development of agriculture because it has an adequate thickness of top soil to plant roots [14]. Based on the earlier study of city government in 2009, this region would serve as agro-tourism area, by looking at the crops plantation and agriculture such as rambutan, mango and papaya as well as potatoes and corn to be produced from this region. However, further study showed that this region has the core advantage to be developed as an integrated tourism area based on ecotourism. The uniqueness of such potential areas of forest, mountain and coastal mangrove forests are integrating, with proper development could become another alternative tourism besides the Bunaken area.

The tourists perception on tourism development area is considered very important, considering how strong the appeal of tourist attraction. In addition, the site should have value of sale to be marketed and tourists are interested in visiting the region in the future. Examined tourist perceptions, experiences and argues that tourist perception is positive and their experiences are beyond expectations based on cultural enrichment and local people friendliness plus local hospitality facilities. Consumers embrace tourism as an activity which personal identity can be constructed autonomously and authentically [15]. Henderson points out that setting appropriate infrastructure and political instability, security and safety greatly affect the perception of tourists to visit to tourism destination [16].

This suggest that unique factors of tourist attractions, accessibility, ancillary, and available amenities in a tourist destination would be meaningless without the rating assessment by tourists. Thus the perception of tourists is the experience of a tourist attraction, events, or relationships obtained by inferring information and give a message.

However, they did not do in-depth study of ecotourism as an attraction. It is implied in the development of tourist area, which neglected the importance of tourists or visitor's perception who have been visited the region. The perception is in the form of comments about the potential area to be developed into an integrated tourist area, which is based on the advantages indicator of Tumpa Mountain area. Therefore, the purpose of this study assessed the perception of tourists to the potential development of the Tumpa mountain region as an integrated ecotourism in the city of Manado, North Sulawesi Province.

\section{MATERIALS AND METHODS Study Area}

Tumpa Mountain located in the Province of North Sulawesi, with $3 / 4$ of its location is included in the administrative area of Manado City and the other part of North Minahasa Regency. There are 4 villages around the area namely Pandu, Molas, Meras and Tongkaina. These villages are part of Manado administrative while Tiwoho is administra-tively part of the North Minahasa Regency.

The height of Mount Tumpa is 400 to $600 \mathrm{~m}$ above sea level (asl) with the highest peak $623 \mathrm{~m}$ 
asl with most hilly topography. The northern part of the mainland leads to the sea thus it is adjacent to the Bunaken National Park, \pm 15 minutes from the entrance of the park on the island of Bunaken.

Tumpa Mountain area has a few natural potentials, ranging from the potential of the mountain, protected forests, smallholders, beaches and mangrove forests. This potencies form a single (integrated) unit which is mutually inseparable. In their Master Plan Tourism [17], Manado Government established this area as an area of forest and mountain ecotourism products.

\section{Data Collection}

This research involved a qualitative approach research method. The results were described by using figures of the percentage. Fieldwork used a questionnaire survey. The sampling method is accidental sample [18] with the number of samples 25 respondents who provide recommendations for the development of ecotourism sites. The questionnaire consists of 13 indicators that provide overall picture of the main potential, two potential support, 3 social and cultural attractions, 6 indicators of accessibility, 5 indicators of facilities, and 4 indicators of ancillary.

\section{Data Analysis}

In the measurement, we used Likert Scale in the form of scoring criteria [19]. The following explanations are: very good (5), good (4), fairly good (3), bad (2) and very bad (1). Scores range categories are: 1.0-1.7 (very bad), 1.8 - 2.5 (bad), 2.6 - 3.3 (medium), 3.4 - 4.1 (good) and 4.2 - 5.0 (very good). Then compared with the analysis of interest rate (level of importance) to measure how important each indicator in condition to be maintained and developed in a tourist location.

\section{RESULTS AND DISCUSSION}

Main Potential Tourism Attraction

The results showed the majority of respondents stated that the potential main attractions of Mount Tumpa area are good, only a small proportion considered as 'fairly good'. In more detail, the respondents' assessment on the potential tourism attraction showed in Table 1.

Potential amazing nature in Tumpa Mount region was assessed as very good by $40 \%$ of respondents and good by $28 \%$ of respondents, and the other $4 \%$ is very bad. The total score for this question amounted to 100 with an average real score of the the item is 4.0 , considered as good.

As many as $64 \%$ of respondents expressed that potential comfortable temperature and humidity is good, while $32.2 \%$ of respondents stated fairly good. The remaining $4 \%$ is bad with a total score of 89 and the average real score for the item is 3.6, included as good.

Respondents expressed very good of $4 \%$ for normal rainfall, $64 \%$ for good, followed by $20 \%$ fairly good, while the remaining $4 \%$ said bad, and $8 \%$ said it is very bad. The total score for this question amounted 88 , with average real score 3.5 which is in good criteria.

Table 1. The Value of Tourist Perception towards the Main Potential Tourism Attraction in Tumpa Mount Area

\begin{tabular}{lrrrrrrrrrrr}
\hline \multicolumn{1}{c}{$\begin{array}{c}\text { Main Attraction } \\
\text { Indicator }\end{array}$} & Tot & \multicolumn{1}{c}{ VB } & & B & & FG & & G & & VG \\
\cline { 2 - 11 } & (N) & & \% & Tot & \% & Tot & $\%$ & Tot & $\%$ & Tot & $\%$ \\
\hline Amazing Nature & 25 & 1 & 4.0 & 0 & 0.0 & 7 & 28.0 & 7 & 28.0 & 10 & 40.0 \\
Comfortable temperature and humidity & 25 & 0 & 0.0 & 1 & 4.0 & 8 & 32.2 & 16 & 64.0 & 0 & 0.0 \\
Normal rainfall & 25 & 2 & 8.0 & 1 & 4.0 & 5 & 20.0 & 16 & 64.0 & 1 & 4.0 \\
Seeing the sunrise and sunset & 25 & 1 & 4.0 & 0 & 0.0 & 5 & 20.0 & 10 & 40.0 & 9 & 36.0 \\
Unique flora & 25 & 0 & 0.0 & 0 & 0.0 & 8 & 32.2 & 12 & 48.0 & 5 & 20.0 \\
Unique fauna & 25 & 1 & 4.0 & 0 & 0.0 & 7 & 28.0 & 12 & 48.0 & 5 & 20.0 \\
Trekking location & 25 & 2 & 8.0 & 0 & 0.0 & 5 & 20.0 & 15 & 60.0 & 3 & 12.0 \\
Hiking location & 25 & 1 & 4.0 & 1 & 4.0 & 8 & 32.0 & 7 & 28.0 & 8 & 32.0 \\
Fun bike location & 25 & 1 & 4.0 & 2 & 8.0 & 5 & 20.0 & 13 & 52.0 & 4 & 16.0 \\
Camping location & 25 & 1 & 4.0 & 1 & 4.0 & 6 & 24.0 & 9 & 36.0 & 8 & 32.0 \\
Spiritual location & 25 & 2 & 8.0 & 0 & 0.0 & 3 & 12.0 & 11 & 44.0 & 9 & 36.0 \\
Coastal beach & 25 & 5 & 20.0 & 7 & 28.0 & 7 & 28.0 & 6 & 24.0 & 0 & 0.0 \\
Mangrove forest area & 25 & 2 & 8.0 & 1 & 4.0 & 3 & 12.0 & 10 & 40.0 & 9 & 36.0 \\
\hline
\end{tabular}

Note: Tot $=$ Total, N = Number, VB = Very Bad, B = Bad, FG = Fairly Good, G = Good, VG =Very Good 
A panoramic view of the sunrise and sunset from the top of Tumpa Mount was assessed. The results showed that $36 \%$ perceived very good and $40 \%$ good. While respondents considered fairly good by $20 \%$ and only $4 \%$ of respondents perceived very bad. The total score is 101 , with average score 4 , stated as good.

Unique potential of flora rated as good by $48 \%$ respondents and very good by $20 \%$ respondents. The remaining $32 \%$ of respondents expressed as fairly good and no respondents expressed bad. The total score is 97 averaged 3.9, thus stated as good.

Total of $48 \%$ respondents expressed that the potential uniqueness of fauna is good, $20 \%$ said very good, $28 \%$ expressed fairly good while the remaining $4 \%$ said it was very bad. The total score is 95, average score is 3.8, included in good.

Potential trekking site assessed as good by $60 \%$ respondents, and $12 \%$ very good, $28 \%$ fairly good, while the remaining $4 \%$ said very bad. With total score of 95 and averaged for 3.7, it is included in good.

As many as $32 \%$ of respondents stated that potential hiking location is very good, $28 \%$ respondents said good, 32\% respondents expressed fairly good. The other was $4 \%$ respondents expressed bad and very bad. The total score is 95 with average score of the real for the item is 3.8 which are good.

Potential location for fun bike was expressed by $52 \%$ of respondents as good, while $16 \%$ of respondents expressed very good, followed by $13 \%$ expressed fairly good. The remaining $8 \%$ of respondents stated bad and $4 \%$ said it was very bad. Total score is 96 with an average score of 3.7 is good.

As many as $36 \%$ of respondents said good and $32 \%$ expressed very good as a camping site and followed by $24 \%$ of respondents expressed fairly good. The other was $4 \%$ said bad and very bad. Total score 97, averaged 3.9 considered as good.

As spiritual locations, $44 \%$ respondents declared as good, $36 \%$ said very good and $12 \%$ expressed good enough. While the remaining $8 \%$ said it was very bad. The total score of 100 with an average score of 4 is good.

Coastal areas that have aesthetic value and suitable for swimming location were assessed good of $24 \%$ respondents, followed by $28 \%$ fairly good and bad, and the other $20 \%$ said it was very bad. The total score was 64 with an average 2.6 which is fairly good.

Mangrove forests serve as ecotourism area, assessed by $40 \%$ respondents as good, $36 \%$ very good and $12 \%$ followed by fairly good, $4 \%$ bad and $8 \%$ very bad. The total score is 98 with an average score of 3.9 which is good.

Assessment by traveler perception towards the potential tourist attraction indicates that the highest value is the amazing nature; see the sunrise and sunset; and spiritual location with real value of a score is 4.0. However, the average value of the overall score at the level of 3.72 is included as good. Thus it can be concluded that nature is main potencies to be developed as tourist attractions in Tumpa Mount area.

\section{Supporting Potential Tourism Attraction}

The supporting potential attractiveness regarded as espousal for the potential inherent core nature in the main natural elements (Table 2). Assessment on the potential supporting found two elements of the attractions that appeal are plantations (coconut and fruit) and cropping patterns of people who settled in the area surround Mount of Tumpa.

Potential of agriculture in the region of Tumpa Mount were expressed as good by $56 \%$ of respondents, $20 \%$ for very good and fairly good, while the remaining $4 \%$ is very bad. The total score for this question is 101 with real average score 3.9 considered as good.

Total of $48 \%$ respondents expressed that the potential farming model of community is good, followed by $28 \%$ respondents stated very good. The others $20 \%$ said fairly good while the remaining $4 \%$ said bad with a total score of 100 and an average score 4, included as good. 
Perception towards Integrated Ecotourism of Tumpa Mountain Area, Manado

(Towoliu \& Takaendengan)

Table 2. The Value of Tourist Perception towards the Supporting Potential of Tourism Attraction in Tumpa Mount area

\begin{tabular}{lrrrrrrrrrrrr}
\hline \multirow{2}{*}{ Indicator of Supporting attraction } & Tot & \multicolumn{2}{c}{ VB } & \multicolumn{2}{c}{ B } & \multicolumn{2}{c}{ FG } & \multicolumn{2}{c}{ G } & \multicolumn{2}{c}{ VG } \\
\cline { 2 - 13 } & (N) & Tot & \% & Tot & \% & tot & \% & tot & \% & tot & \% \\
\hline Agriculture & 25 & 1 & 4.0 & 0 & 0.0 & 5 & 20.0 & 14 & 56.0 & 5 & 20.0 \\
Farming model & 25 & 0 & 0.0 & 1 & 4.0 & 5 & 20.0 & 2 & 48.0 & 7 & 28.0 \\
\hline
\end{tabular}

Note: Tot $=$ Total, N = Number, VB = Very Bad, B = Bad, FG = Fairly Good, G = Good, VG =Very Good

Overall assessment of supporting factors by respon-dents averaged for 3.94 that included as good. It can be concluded that the factors which supporting the main component of a tourism attraction should always be maintained, not to be marginalized, because they have uniqueness attraction in ecotourism scheme.

\section{Socio-cultural Potential Tourism Attraction}

Assessment of respondents toward sociocultural community attraction surrounding the Tumpa Mount is good (Table 3). Livelihoods systems around Mount Tumpa are farmers and fishermen. As $40 \%$ respondents included as good, $8 \%$ rate as very good and $48 \%$ fairly good, while the remaining $4 \%$ rate as bad. The total score for this question amounted to 88 with an average score of the real for the item is 3.5 which is good.

As many as $40 \%$ of respondents rate as good for the spiritual life of the community, and $36 \%$ rate as very good and $20 \%$ good enough. Otherwise, the remaining $4 \%$ rate as bad. The total score for the question is 102 with average rating scores for 4.1, which is good.

Local wisdom of people living in the region perceived $32 \%$ of respondents as very good. Followed by $16 \%$ respondents expressed good and $40 \%$ fairly good while the remaining $4 \%$ is bad and $8 \%$ is very good. The total score is 90 , average score was 3.6 considered as good.

From the assessment on the socio-cultural tourism attraction, we obtained that historical relic such as traditional values lead to a better life to be maintained, followed by local wisdom and spiritual life. But in general, the average overall score for the indicators is 3.53 (good). This means sociocultural attraction needs to be maintained and developed, regards to the community-based ecotourism.

\section{Accessibility in Tumpa Mount area}

In tourism development, the availability of infrastructure such as transportation modes, mileage, condition and road safety, and others affect tourist's decision on their destination. Factor of speed, comfort, safety and convenience are needed for a destination that deemed fit for sale. The following Table 4 showed tourist ratings to the existence of accessibility to Tumpa Mount area.

Availability of transportation mode to the locations assessed $44 \%$ as very good, $32 \%$ good and $24 \%$ fairly good. No respondents stated bad or very bad. The total score is 105 , with average value 4.2, it is included as good.

Distance from the airport or harbor to the location assessed $24 \%$ as very good and $28 \%$ good followed by $24 \%$ fairly good. While $20 \%$ rate is bad, and $4 \%$ is very bad. The total score amounted to 87 , with an average score 3.5 , which is good.

Total of $56 \%$ respondents rate good, $32 \%$ rate as very good and $8 \%$ is fairly good for assessing on road conditions. While the remaining $4 \%$ rate bad. Total score is 104 , with an average value of 4.2 , considered as good.

For safety road, 36\% respondents rate good, $28 \%$ rate very good and $20 \%$ fairly good. While $8 \%$ rate bad, and $4 \%$ is very bad. Total score of 94 with average 3.8 , categorized as good.

Table 3. The Value of Tourist Perceptions towards the Social-culture Potential in Tumpa Mount Area

\begin{tabular}{|c|c|c|c|c|c|c|c|c|c|c|c|}
\hline \multirow{2}{*}{$\begin{array}{c}\text { Social-culture attraction } \\
\text { Indicator }\end{array}$} & \multirow{2}{*}{$\begin{array}{l}\text { Tot } \\
\text { (N) }\end{array}$} & \multicolumn{2}{|c|}{ VB } & \multicolumn{2}{|c|}{ B } & \multicolumn{2}{|c|}{ FG } & \multicolumn{2}{|c|}{$\mathbf{G}$} & \multicolumn{2}{|c|}{ VG } \\
\hline & & Tot & $\%$ & Tot & $\%$ & tot & $\%$ & tot & $\%$ & tot & $\%$ \\
\hline Livelihood & 25 & 0 & 0.0 & 1 & 4.0 & 12 & 48.0 & 10 & 40.0 & 2 & 8.0 \\
\hline Spiritual living & 25 & 0 & 0.0 & 1 & 4.0 & 5 & 20.0 & 10 & 40.0 & 9 & 36.0 \\
\hline Local-wisdom & 25 & 2 & 8.0 & 1 & 4.0 & 10 & 40.0 & 4 & 16.0 & 8 & 32.0 \\
\hline
\end{tabular}

Note: Tot $=\mathrm{N}=$ Number, Total, VB = Very Bad, B = Bad, FG = Fairly Good, G = Good, VG =Very Good 
Table 4. The Value of Tourist Perception towards Existed Accessibility in Tumpa Mount area

\begin{tabular}{|c|c|c|c|c|c|c|c|c|c|c|c|}
\hline \multirow{2}{*}{$\begin{array}{l}\text { Accessibility } \\
\text { Indicator }\end{array}$} & \multirow{2}{*}{$\begin{array}{l}\text { Tot } \\
\text { (N) }\end{array}$} & \multicolumn{2}{|c|}{ VB } & \multicolumn{2}{|c|}{ B } & \multicolumn{2}{|c|}{ FG } & \multicolumn{2}{|c|}{$\mathbf{G}$} & \multicolumn{2}{|c|}{ VG } \\
\hline & & Tot & $\%$ & Tot & $\%$ & Tot & $\%$ & Tot & $\%$ & Tot & $\%$ \\
\hline Transportation mode & 25 & 0 & 0.0 & 0 & 0.0 & 6 & 24.0 & 8 & 32.0 & 11 & 44.0 \\
\hline Distance of site to airport, harbor, etc & 25 & 1 & 4.0 & 5 & 20.0 & 6 & 24.0 & 7 & 28.0 & 6 & 24.0 \\
\hline Existing road & 25 & 0 & 0.0 & 1 & 4.0 & 2 & 8.0 & 14 & 56.0 & 8 & 32.0 \\
\hline Safety of road & 25 & 1 & 4.0 & 2 & 8.0 & 6 & 24.0 & 9 & 36.0 & 7 & 28.0 \\
\hline Telecommunication system & 25 & 0 & 0.0 & 0 & 0.0 & 5 & 20.0 & 7 & 28.0 & 13 & 52.0 \\
\hline Terminal & 25 & 2 & 8.0 & 4 & 16.0 & 7 & 28.0 & 5 & 20.0 & 7 & 28.0 \\
\hline
\end{tabular}

Note: Tot $=\mathrm{N}=$ Number, Total, VB = Very Bad, B = Bad, FG = Fairly Good, G = Good, VG =Very Good

Telecommunications systems rated $52 \%$ as very good, $28 \%$ good and $20 \%$ fairly good. No respondents felt the telecommunications is bad. The total score on the indicator is 108 , with an average 4.3, which categorized as good.

As many as $28 \%$ respondents rate as very good, $20 \%$ good and $16 \%$ fairly good for the condition of traditional terminal. While the $16 \%$ rate as bad and $8 \%$ very bad. The total score is 86 with average value 3.4 , which is fairly good.

Based on the perception of tourists towards accessibility above, it is implied that the system of telecommunications and transportation modes rated highly by respondents. The five indicators Assessment towards the accommodation sur-round the site showed $60 \%$ respondents answered very good, $16 \%$ good and $20 \%$ fairly good. Otherwise, $4 \%$ respondents are very bad. The total score for this indicator is 107 , with average value of 4.3 , which is good.

For restaurants, $48 \%$ of respondents rate good, $32 \%$ rate as very good and $20 \%$ fairly good. None of respondents perceived the restourants as bad. The total score for the restourants are 103, with average value of 4.1, which categorized as good.

Availability of clean water in the area was $76 \%$ as very good, $20 \%$ good while $4 \%$ fairly good. Total scores for is 116 with average value of 4.6 , which is very good.

For electricity, $72 \%$ respondents perceived very good, followed by $12 \%$ rate good and $12 \%$ other is fairly good. No respondents expressed bad on the elactrical system. The total score on the item is 114 with average value of 4.6 , which is very good. have average value of 3.89, which is categorized as good. Thus it can be concluded that the accessibility in the Tumpa Mount Area were assessed worthy and good. The government only needs to reorganize things that were deemed to be lacking.

\section{Facilities Service}

Service of facilities for tourists is a means of supporting factor that very important for tourism destination in order to meet the needs of tourists during the journey. The results of respondents' perceptions on service facilities in Tumpa Mount area showed in Table 5 below.

Tourist information center was rated by the respondents as $48 \%$ very good, $28 \%$ good, $20 \%$ fairly good and $4 \%$ bad. The total score is 104 with average value of 4.2 , which categorized as good.

Based on the survey, we can assume that the availability of clean water and electricity ware rated highly by respondents. However, the average total value of 4.35 is generally good. This means that direct various facilities have been provided for the development of ecotourism in Tumpa Mount area.

\section{Ancillary services}

Ancillary services are often referred as a complement provided by local government on tourist destinations, both for tourists and tourism actors. Services provided include physical development and coordinate all sorts of activities with the legislation on tourist destination. Ancillary services in Tumpa Mount area can be seen in Table 6 below. 
Perception towards Integrated Ecotourism of Tumpa Mountain Area, Manado

(Towoliu \& Takaendengan)

Table 5. The Value of Tourist Perception towards Tourism Facility Service in Tumpa Mount area

\begin{tabular}{lrrrrrrrrrrr}
\hline \multicolumn{1}{c}{\begin{tabular}{c} 
Tourism facility service \\
\multicolumn{1}{c}{ Indicator }
\end{tabular}} & Tot & \multicolumn{1}{c}{ VB } & \multicolumn{1}{c}{ B } & \multicolumn{1}{c}{ FG } & \multicolumn{1}{c}{ G } & \multicolumn{1}{c}{ VG } \\
\cline { 2 - 11 } & $\mathbf{( N )}$ & Tot & \% & Tot & \% & Tot & \% & Tot & \% & Tot & \% \\
\hline Accommodation & 25 & 1 & 4.0 & 0 & 0.0 & 5 & 20.0 & 4 & 16.0 & 15 & 60.0 \\
Restaurant & 25 & 0 & 0.0 & 0 & 0.0 & 5 & 20.0 & 12 & 48.0 & 8 & 32.0 \\
Clean Water & 25 & 0 & 0.0 & 1 & 4.0 & 0 & 0.0 & 5 & 20.0 & 19 & 76.0 \\
Electrical System & 25 & 0 & 0.0 & 0 & 0.0 & 3 & 12.0 & 3 & 12.0 & 18 & 72.0 \\
Tourism Information Center & 25 & 0 & 0.0 & 1 & 4.0 & 5 & 20.0 & 7 & 28.0 & 12 & 48.0 \\
\hline
\end{tabular}

Note: Tot $=$ Total, N = Number, VB = Very Bad, B = Bad, FG = Fairly Good, G = Good, VG =Very Good

Table 6. The Value of Tourist Perception towards Ancillary Service in Mount Tumpa area

\begin{tabular}{llrrrrrrrrrr}
\hline \multicolumn{1}{c}{$\begin{array}{c}\text { Ancillary service } \\
\text { Indicator }\end{array}$} & \multicolumn{1}{c}{ Tot } & \multicolumn{2}{c}{ VB } & \multicolumn{1}{c}{ B } & \multicolumn{1}{c}{ GE } & \multicolumn{3}{c}{ G } & VG \\
\cline { 2 - 12 } & (N) & Tot & \% & Tot & \% & Tot & \% & Tot & \% & Tot & \% \\
\hline Organizer & 25 & 1 & 4.0 & 1 & 4.0 & 7 & 28.0 & 13 & 52.0 & 3 & 12.0 \\
Guide & 25 & 1 & 4.0 & 2 & 8.0 & 6 & 24.0 & 9 & 36.0 & 7 & 28.0 \\
Regulation & 25 & 3 & 12.0 & 2 & 8.0 & 5 & 20.0 & 9 & 36.0 & 6 & 24.0 \\
Tour Travel & 25 & 0 & 0.0 & 3 & 12.0 & 6 & 24.0 & 9 & 36.0 & 7 & 28.0 \\
\hline
\end{tabular}

Note: Tot $=$ Total, $\mathrm{N}=$ Number, VB = Very Bad, B = Bad, FG = Fairly Good, G = Good, VG =Very Good

Assessment on tour organizer for the region showed $52 \%$ respondents rate good, followed by $12 \%$ very good and $28 \%$ fairly good. Whereas the same score $4 \%$ assessed as bad and very bad. The total score is 91 with average value of 3.6, categorized as good.

Tour guides were assessed $36 \%$ as good, $28 \%$ as very good and $24 \%$ considered fairly good. While $8 \%$ respondents rate bad and $4 \%$ rate very bad. The total score is 94 with average value of 3.8 , included as good.

Assessment of tourism regulation that apply on tour found that $36 \%$ of respondents rate as good, $24 \%$ good and $20 \%$ fairly good. While $12 \%$ perceived bad and $8 \%$ perceived very bad. Total score is 88 , with average value of 3.5 considered as good.

Travel business activities within the area were perceived $36 \%$ as good, $28 \%$ as very good, $24 \%$ fairly good and $12 \%$ as bad. The total score is 94 with average value of 3.8, categorized as good.

The assessment of the tourists' perception towards ancillary service implied that the highest values found in business tour indicators, and followed by guide and tourism regulation. But overall average value for the availability of additional services in the area is 3.8, which included in good category. Although included in good category, the government needs to make improvements for additional facilities for tourist activities.

\section{Level of Importance}

Analysis on the level of importance of various indicators in diverse potential tourism in Tumpa Mount area showed in Table 7. The 13 indicators of the main attractions that exist in the Tumpa Mount area need to be developed as seen from scoring average respondent which amounted to 3.94. It is important to develope the area for tourism based on the perception that included in good indicator. In addition, respondent's perception on supporting attraction and socio-cultural attractions has essential predicate to be maintained and developed. This can be seen from the average score for the second assessment on the additional attraction; 4.16 for supporting attraction and 3.76 for sociocultural attractions.

The local site area development was schemed as an alternative tourism attraction based on integrated ecotourism. This potential will become an integral part of its own appeal, support each other and are unique to the destination city of Manado.

Assessment on accessibility indicators for all road conditions implied that according to the predicate, telecommunication system is very important to be developed. Although the average value of all the important is 4.22. Tourism should provide comfort and ease in reaching the tourism location. Modes of transportation, proximity distance between the airport and port as well as safety and comfort of road will create a good image for tourists visiting a destination. 
Table 7. The Tourist Perception towards the Level of Importance on Potential Tourism in Tumpa Mount area

\begin{tabular}{|c|c|c|c|c|}
\hline Indicator of Potential Tourism Attraction & $\begin{array}{c}\text { Tot } \\
\mathbf{N}\end{array}$ & $\begin{array}{r}\text { Tot } \\
\text { Sc }\end{array}$ & $\mathbf{R}$ & $\mathbf{P}$ \\
\hline \multicolumn{5}{|l|}{ Main Attraction } \\
\hline Comfortable temperature and humidity & 25 & 94 & 3.6 & Important \\
\hline Normal rainfall & 25 & 89 & 3.6 & Important \\
\hline Unique flora & 25 & 105 & 4.2 & Important \\
\hline Unique fauna & 25 & 102 & 4.1 & Important \\
\hline Trekking location & 25 & 98 & 3.9 & Important \\
\hline Hiking location & 25 & 105 & 4.2 & Important \\
\hline Fun bike location & 25 & 91 & 3.6 & Important \\
\hline Coastal beach & 25 & 94 & 3.8 & Important \\
\hline Mangrove forest area & 25 & 105 & 4.2 & Important \\
\hline \multicolumn{5}{|l|}{ Supporting Potential } \\
\hline Agriculture & 25 & 103 & 4.1 & Important \\
\hline Farming model & 25 & 105 & 4.2 & Important \\
\hline \multicolumn{5}{|l|}{ Social-Culture Attraction } \\
\hline Livelihood & 25 & 90 & 3.6 & Important \\
\hline Spiritual Living & 25 & 98 & 3.9 & Important \\
\hline Local wisdom & 25 & 94 & 3.8 & Important \\
\hline Terminal & 25 & 97 & 3.9 & Important \\
\hline \multicolumn{5}{|l|}{ Tourism Facility Service } \\
\hline Accommodation & 25 & 115 & 4.6 & Very Important \\
\hline Restaurant & 25 & 107 & 4.3 & Important \\
\hline Clean Water & 25 & 115 & 4.6 & Very Important \\
\hline Electrical system & 25 & 113 & 4.5 & Important \\
\hline Tourism Information Center & 25 & 110 & 4.4 & Important \\
\hline \multicolumn{5}{|l|}{ Ancillary } \\
\hline Organizer & 25 & 96 & 3.8 & Important \\
\hline Guide & 25 & 97 & 3.9 & Important \\
\hline Tourism Regulation & 25 & 95 & 3.8 & Important \\
\hline Tour and Travel & 25 & 105 & 4.2 & Important \\
\hline
\end{tabular}

Note: Tot $\mathrm{N}=$ Total Number, Tot $\mathrm{Sc}=$ Total Score, $\mathrm{R}=$ Rating, $\mathrm{P}=$ Predicate

In accordance with the mission of making the city of Manado convenient for residents and visitors, the govern-ment should also give attention to the develop-ment of local area attractiveness into a convenient tourism destination for anyone.

The tourism service facilities that were ranked very important are accommodation, restaurants, electricity and clean water. This assessment implied that the tourists are very concerned with the presence of food and beverage services provid-er during their trip. The availability of accommo-dation, water, electricity and information centers received the predicate of very important, in addition to the restaurant which was considered important. The total average score for overall indicator on the facilities' availability is 4.48 with predicate very important. Governments and stakeholders must concern on the needs of tourist for supporting facilities in the area. 
The predicate to the ancillary/additional facilities - managers, guides, tools and rules of travel business - is considered important by the respondents (Table 7 ) with an average score of overall value of 3.93 (important). Tour actors should pay attention to the additional facilities that tourists needed in order to develop the tourism attraction surround the Tumpa Mount area.

The results from tourists' perception showed positive values, i.e. good and important in the development of ecotourism destinations. Positive perceptions on destination will give good image [20] and facilitate the development of marketing strategies [21]. Level of importance on the development of ecotourism destination [22], will help improve and manage ecotourism as well as useful resources for planning integrated tourism development.

\section{CONCLUSION}

The assessment of each indicator component has average value as follows: 3.72 for main attraction, 3.94 for supporting attraction, 3.52 for socio-cultural attraction, 3.89 for accessibility and 3.8 for ancillary. Each of these values is at the level of $>3.5$ which means good indicator to be developed. Otherwise, the importance level of potencies to be developed showing the average value of 3.94 for the main potential, 4.16 for supporting attractions, 3.76 for socio-cultural attractions, 4.22 for accessibility, 4.48 service facilities and 3.93 for ancillary. Based on these two assessments, the potential for ecotourism in the Tumpa Mount area are 'good' and 'important' to be developed as an integrated tourism area. The tourist perception matched the plan of integrated ecotourism deve-lopment will facilitate the management considera-tion for decision making and form a positive image for the tourism destination in Tumpa Mount area.

\section{ACKNOWLEDGEMENTS}

The author regards to Directorate General of Higher Education via Research Institution in State Polytechnic of Manado which funded this research.

\section{REFERENCES}

[1] Rattan, J. K., P.F.J. Eagles, and H.L. Mair. 2012. Volunteer tourism: Its role in creating conservation awareness. Journal of Ecotourism 11(1), 1-15.

[2] TIES. 2000. Ecotourism statistical fact sheet. The International Ecotourism Society.
[3] Boo, E. 1990. Ecotourism: the potential and pitfalls (2 Vols). World Wildlife Fund, Baltimore.

[4] Lascurian, C. 1996. Tourism ecotourism and protected areas. Papers of Tourism Workshops. The World Congress IV on National Park and Protected Areas. Caracas, Venuzuela.

[5] Weaver, B. D. (Ed). 2001. The encylopedia of ecotourism. CAB International. Wallington Oxon, UK.

[6] Weaver, B. D. 2001. Ecotourism. John Wiley \& Sons Limited. Australia.

[7] Weaver, B. D. 2008. Ecotourism, $2^{\text {nd }}$ Edition. John Wiley \& Sons Limited. Australia.

[8] Peggy, J. P. 2005. Ecotourism. Kid Haven Press. New York.

[9] Singh, J. 2010. Ecotourism. I.K. International Publishing House Pvt Ltd. New Delhi.

[10] Damanik J., H.F. Weiber. 2006. Ecotourism planning: from theory to application. Yogyakarta. Andi Offset 10, 37-38.

[11] Pegas, F., A. Coghlan, and V. Rocha. 2012. An exploration of a mini-guide programme: Training local children in sea turtle conservation and ecotourism in Brazil. Journal of Ecotourism 11(1), 48-55.

[12] Statistical Central Office of North Sulawesi. 2013. North Sulawesi statistical data. Statistical Central Office of North Sulawesi. Manado.

[13] Bunaken National Park Management Board. 2010. Final Report: formulation study of potential tourism and culture, Manado City. PT. Megumi Abadi.

[14] Agribusiness Department of Manado. 2009. Development of agrotourism area in Mount Tumpa to Manado World Tourism City. Agribusiness Department Office of Manado.

[15] Rahman, M.S. 2012. Exploring tourists' perception: the case of Bangladesh Tourismos: An International Multidisciplinary Journal of Tourism 7 (1), 81-98.

[16] Henderson, J.C. 2011. Tourism development and politics in the Philippines. Tourismos: An International Multidisciplinary Journal of Tourism 6 (2), 159-173.

[17] Government of Manado City. 2012. Regional tourism master plan of Manado City (RIPPDA). Government of Manado City. Manado.

[18] Antara, M. 2009. Research methodology of tourism in Bali. Graduate Program of Udayana University. Denpasar. 
[19] Riduwan. 2009. Measurement scale of research variables. Alfabeta. Bandung.

[20] Coban, S. 2012. The effects of the image of destination on tourist satisfaction and loyalty: the case of Cappadocia. European Journal of Social Science 29(2), 222-232.

[21] Rajesh, R. 2013. Impact of tourist perceptions, destination image and tourist satisfaction on destination loyalty: a conceptual model. Revista de Turismo y Patrimonio Cultural 11 (3), Special Issue, 6778.

[22] Yacob, M.R., A. Radam, Z. Zamdin. 2011. Tourists perception and opinion towards ecotourism development and management in Redang Island Marine Parks in Malaysia. International Business Research 4(1), 62-73. 